\title{
Study on Learning and Professional Development of Middle School English Teachers in the Context of Classroom Teaching
}

\author{
Hao Jingjing \\ Qilu Normal University
}

Keywords: classroom teaching; middle school English teachers; professional development

\begin{abstract}
English is the first language for international communication. The proposal of new curriculum standard means higher requirements for the teaching of teachers, how to better teach, and effectively improve student learning efficiency is a question that must be taken into account by every middle school English teacher. In order to effectively improve the classroom teaching efficiency, the teachers' quality should be improved first, and then to effectively promote teachers' professional development. Therefore, this paper analyzes and studies meaning and significance of professional development of middle school English teachers in the context of classroom teaching, and proposes relevant strategies.
\end{abstract}

With the development of society, China's basic education has also been in constant development and the traditional education ideas have gradually been no longer suitable for today's teaching. How to improve classroom teaching efficiency of teachers and improve students' learning efficiency is the most important issue faced by teachers. Therefore, teachers must deeply understand the standards of the new curriculum, and know about the actual English level of the objects they teach, and continue to develop ideas in teaching, and also constantly update the teaching perspectives, so that students can experience the joy of learning. When facing the new curriculum, teachers will be deeply aware that the teaching burden on their shoulders has become heavier. It's no longer sufficient to meet the needs of classroom teaching by relying only the traditional teaching thinking. It's necessary for teachers to make effective use of classroom resources to help students develop autonomous earning habits ${ }^{[1]}$. Therefore, it's an inevitable trend in English teaching today to highly advocate professional development of teachers to a certain extent.

\section{Professional Development Meaning of Middle School English Teachers in the Context of Classroom Teaching}

Generally speaking, professional development is a growing process of knowledge and ability of each person before and during their employment. For teachers, the degree of professional development represents their knowledge level and teaching ability. The main purpose of professional development is to promote the teachers to effectively play and develop their skills. As is known to all that the focus of training teachers is to help them become good educators, and the focus of the development of teachers is to let them decide what their expertise is, thus they can better use their own experience to make themselves be with more flexible development ${ }^{[2]}$. Teachers do not conduct professional development randomly, and instead they have targeted development at each stage. Besides the professional development is also continuous and systematic, and the continuity mainly requires that teachers should study continuously in each teaching stage to improve their own teaching quality, and constantly seek the new solutions when encountering any problems. The systematic means that teachers are not a single individual to improve the professional ability, but the process for the entire educational institution to improve the overall ability. Therefore, the systematic not only considers the development of individuals, but also considers the development of institutions to some extent.

Professional development means that teachers can better acquire new knowledge and skills to improve their teaching capabilities, and enrich their knowledge, while injecting more vitality into education practice. In addition, professional development of English teachers can help them better 
improve their income and reputation ${ }^{[3]}$. There are two kinds of internal and external factors in conducting the professional development. The internal factor is that teachers need to have opportunities for professional development in teaching process, as well as the opportunities to improve professional skills and acquire new skills. The external factor is that it's difficult for teachers to face various problems in teaching process at the early stage of education. However, with the continuous improvement of knowledge and continuous growth of capabilities, teachers have acquired more about the latest knowledge, and they can better improve their skills to help them better teach middle school students. Although the two factors have caused most teachers to fall into huge pressure of professional development, the pressure is precisely a driving force, which makes the teachers eager to be outstanding in the fierce competition while prompting teachers to conduct the professional development, thus they can seek for their maximum benefits in their own profession. Therefore, professional development has become a bridge for English teachers to improve their capabilities.

\section{Professional Development Significance of Middle School English Teachers in the Context of Classroom Teaching}

When conducting teaching work, teachers should effectively use the language tools. Language is not only a bridge for people to communicate with others, but also a major tool for foreign language teachers to conduct teaching, and it is even a medium for teachers to improve their abstract thinking ability. The quality of the language used, organized by Middle school English teachers in the classroom, and the language they apply to teach knowledge, the corresponding quality can affect the classroom teaching of teachers to certain extent, thereby affecting the learning efficiency of students $^{[4]}$. Therefore, in order to become a qualified English teacher, one should first be with special English teaching skills. Among them, the use of effective English language for classroom teaching and the successful use of the English language throughout each teaching process is the teaching method that is essential for each English teacher to master.

The teachers with rich knowledge and high teaching skills are highly demanded for all educational institutions, but this is not enough. If teachers do not have a certain extent of identification with the major they teach, there's no definite attitude, which will cause teachers to doubt about them, and thus they are unable to be responsible for students. If the professional knowledge and professional skills are always classified into a category that whether teachers can grasp, then the professional attitudes are generalized to willingness or unwillingness. The professional attitude here includes professional ideals, professional orientation and other aspects. The professional ideals of teachers themselves are largely their longing for becoming independent and mature teaching scholars. The professional ideals to some extent have made teachers be more aware of their goals, allowing teachers to better conduct professional development. An English teacher with strong professional ideals is able to strongly identify and pride in her education career. In this way, teachers are willing to pay more attention to their educational career and are willing to devote their lifetime life to education.

\section{Professional Development Strategies of Middle School English Teachers in the Context of Classroom Teaching}

The traditional teaching mode focuses on hard teaching and hard practice, which is not only boring but also time consuming. Reflective teaching is a new type of teaching, which to a certain extent makes students have better reflection, and that they can participate in learning voluntarily. This mode should be first applied to teachers, because teachers are the source of knowledge for students. Under the requirements of the new curriculum reform, teachers should not only learn how to teach students, but also how to teach them skillfully. Skillfully refers to not only the teaching techniques created by teachers themselves, but also the tricks learned from those teachers who have superior teaching skills ${ }^{[5]}$. Before teachers teach students, they should first prepare lessons and reflect on the contents to be taught, as well as a series of the classroom teaching contents such as 
exercises and after-school review and preview, etc. For an excellent English teacher, all these above are not enough, and they should also reflect on the relationship between teachers and students, as well as the way for teachers to get along with students, reflect on the gap between themselves and other teachers, including their own deficiencies. Through these reflections, teachers can better improve their own teaching quality, and also enhance their professional quality, so that they are more satisfied with their own teaching achievements, and they can make students feel more passionate about learning, and they are more active in joining English learning. In this regard, the teaching efficiency has also been improved while teachers are getting along well with the students, which is a double gain.

English is a foreign language. For students, the teachers should be required to have high teaching capabilities with respect to listening, speaking, reading, and writing, etc. Furthermore, for middle school students, the students, the English question volume and difficulty are increased obviously, which to a certain extent requires teachers to abandon the traditional teaching mode and adopt new teaching strategies. Therefore, teachers are required to strengthen their inquiry capabilities in their professional development. Teachers should design different teaching methods for each section, and understand the progress and learning status of students for each template, so that they can implement the classroom teaching better and more effectively. The traditional teaching mode is very simple, and the corresponding explanation methods often make the classroom very boring, thereby resulting in poor classroom efficiency. In this regard, teachers can effectively carry out inquiry professional development strategies to improve classroom efficiency. For example, in the listening class, teachers should be with certain teaching goals, so that the students can read and write better while listening and speaking. This requires teachers to explore the learning process of each student and develop effective teaching strategies. In the reading class, teachers should grasp the depth and breadth of reading, and grasp the principle of proportionality. This is the basis for allowing the students to gradually grasp the knowledge. Anyway, haste makes waste is a problem that should not be neglected by every teacher. The teachers should connect what the students have learned with extracurricular knowledge, so as to make students conduct association and exploration through familiar things. In this way, students will be more interested in what they have learned, and they will be better able to grasp the reading knowledge. Moreover, for the new vocabularies, teachers also need to do in-depth exploration, and mine learning patterns suitable for each student, effective classroom teaching should be taken for students, and only in this way can other teaching modes be well implemented.

The teachers should read books, newspapers, magazines, and other books related to professional theories as much as possible when conducting the teaching. For example, Words of English Teaching Masters and Foreign Language Education and other books, while enriching their own academic knowledge, the teachers should also makes friends with others through books to expand the scope of friends, and exchange the knowledge gained through reading and teaching concepts with more people ${ }^{[6]}$. The teachers should develop the habit of taking reading notes and teaching notes, and reflect their deficiencies and find out their own advantages from the books, and then is to improve their theoretical level and strengthen their professional capabilities through the academic thesis.

Teaching should not be confined to the classroom but the educational activities should be carried out in many aspects. Teachers should set up a small library in classroom, so that the students are no longer limited to a classroom, a textbook and an exercise book. In the "library", there should be some easy-to-understand English books, teaching radios and other items. In addition to establishing a "library", it is also necessary for teachers to make effective use of extramural resources, such as to conduct the English friendship with other schools, allowing students to learn and communicate with each other, thus to improve their English communicative competence ${ }^{[7]}$. If the library in the class cannot meet needs of the majority students, students should also be organized to study in large libraries outside the school. In this way, the students' English views can be broadened and their English capabilities can be improved. The network is now a very popular term, which is also an effective way to acquire knowledge. Regarding to this, teachers can allow students to watch the 
English movies, English short films, English speeches, and others to enrich their knowledge.

During their tenure, the teachers should actively participate in exchange activities organized by schools, and they should communicate and exchange with teachers of related-major in the school to learn from each other, thus to improve their teaching ability. When conducting academic exchanges outside the school, the teachers should learn from the excellent teaching models outside the school as much as possible, and ask them for advice humbly, thus to make themselves develop quickly. Meanwhile, teachers should also watch good teaching videos, and participate in teaching skill competitions held in and outside the school as much as possible to find excellent teaching methods, and promote themselves to be renewed in teaching methods, so that students have a strong interest in learning, and there will be a qualitative leap in the teaching quality.

\section{Conclusion}

In sum, education is a long way to go, and it requires the active exploration of each teacher. The teaching quality of English education requires the common efforts of each teacher. For teachers, its own professional development has a profound influence on the teaching quality, which in turn affects the classroom teaching efficiency, and the learning quality of the students. The teachers should constantly improve their comprehensive qualities by combining with the social development trends, thus to contribute their own strength to the advancement and development of education.

\section{Acknowledgements}

Project name: A Study on Learning and Professional Development of Middle School English Teachers in the Context of Classroom Teaching

Project number: 17CWZJ25JJ2017.

\section{References}

[1] Jiang yuhong. Study on the level of teaching efficacy in classroom interaction scenarios -implications for the professional development of English teachers in colleges and universities in southwest minority areas [J]. National education research, 2011(3):86-90.

[2] Wang junfang. Contents and effective ways of professional development of English teachers in middle schools -- learning organization [D]. Northeast normal university, 2009.

[3] Ying jianfeng, li yanqing. Investigation and countermeasures of professional development of English teachers in primary and secondary schools -- a case study based on training programs [J]. Crazy English (theoretical edition), 2010(3):156-160.

[4] Zhu houmin. Research on the professional development and teaching skills of middle school English teachers under the new curriculum reform [J]. Journal of qiongzhou university, 2011, 18(1):137-138.

[5] Zhang huijun, liu mantang, Chen jing. Analysis on the current situation of professional development of English teachers in rural middle schools and research on teacher training programs [J]. Journal of shaanxi preschool normal college, 2009, 25(4):120-123.

[6] Lang ping. A study on the practical knowledge and generative mechanism of the professional development of English teachers in middle schools [D]. Xi 'an international studies university, 2011.

[7] Lu yi. Study on the current situation, problems and countermeasures of English teachers in middle schools -- taking yantai district as an example [D]. Shandong normal university, 2009.

About the author: Hao jingjing (1981-), female, shandong jinxiang, master, lecturer in foreign language institute of qilu normal university, the research direction is English class and teaching theory. 